\title{
Marcin Czyżniewski
}

Nicolaus Copernicus University in Toruń (Poland)

\section{Nonpartisan Electoral Committees in Local Government Elections in Poland in 2018}

\begin{abstract}
The article presents the result of quantitative research on local government elections in Poland carried out on October 21 and November 4, 2018. Its goal is to examine the proportions of lists registered by political parties and nonpartisan electoral committees and the mandates they have obtained. This proportion shows the degree of presence of political parties in local governments of various levels and sizes. The data were selected so that all provinces in Poland were examined (16), a number of districts were randomly selected (in provinces with less than 20 districts, data from half districts were examined, in provinces with over 20 districts, from one third). Within the selected districts, all communes were examined. The quantitative research shows that local governments elected in 2018 are not political only in small and medium-sized communes, in which the councils are made up mostly of councilors who were candidates from nonpartisan committees.
\end{abstract}

Keywords: local governments, local elections, Poland, nonpartisan committees

\section{Introduction}

Democratic local government is one of the greatest achievements of political changes in Poland after 1989. Poles, in the vast majority, appreciate the role of local governments, and especially the fact that many important decisions regarding their immediate environment are made at the local and regional level. Local government is not a simple transfer of central government to a lower level, with its mechanisms, principles, and divisions. This is visible, among others, in how the political parties influence the activities of the local government.

The involvement of political parties in the local government has long been in the sphere of interest of researchers. The formulated conclusions not only describe the existing reality but are the basis for the discussion on electoral behaviors, the awareness of political choice, the importance of local government in social life and postulates of changes in law. So far, the largest studies, using the largest amount of data, have been carried out by Gendźwiłł 
and Żółtak (2012). Their research concerned the elections in 2002, 2006, and 2010, covered all candidates for commune and district councils and for the office of city mayors. The obtained results show a large area in which political parties are not present and which is occupied by local social movements or strong leaders not identifying, at least officially, with any party. This particularly applies to smaller cities and communes. P. Swianiewicz (2010, p. 18) believes that the percentage of commune councilors associated with political parties in Poland is among the lowest in Europe. In cities over 100,000 inhabitants, and especially in province local governments, the situation is different, there the domination of political parties is clear.

\section{Objectives and Area of Research, Methodology}

The article presents the result of quantitative research on local government elections in Poland carried out on October 21 and November 4,2018. Its goal is to examine the proportions of lists registered by political parties and nonpartisan electoral committees and the mandates they have obtained. This proportion shows the degree of presence of political parties in local governments of various levels and sizes.

In the article, I examine the proportion of partisan and non-partisan committees that have introduced their candidates to local governments of different levels, as well as the proportion of seats filled by partisan and non-partisan candidates. The division of data shows whether the level of presence of political parties depends on the level of selfgovernment and, in the case of municipalities, on their size. I compare this data with data on all registered electoral lists. If the proportions of all reported partisan and non-partisan lists and those lists from which candidates were introduced into the government will be similar, this means that the level of presence of political parties in local governments is simply the result of such an electoral offer. In other words, the comparison of data shows whether voters are more likely to choose non-partisan candidates because there is proportionally a larger number of them running than partisan candidates or are they favoring these candidates, even though there is fewer of them than of partisan candidates. A similar study is conducted regarding city mayors. In this way, I want to examine whether the level of presence of political parties in Polish local governments is an informed decision of voters favoring a specific group of candidates (partisan or non-partisan) or merely a statistical case resulting from the electoral offer presented to them - as much as quantitative surveys allow.

Although the article is based solely on quantitative research, it can, to some extent, help to understand the reasons behind the support of political parties and nonpartisan committees in local governments. The survey is based on data on the results of the elections made available by the National Electoral Commission (Państwowa Komisja Wyborcza). These were data on electoral lists for commune (gmina), district (powiat), and province (województwo) 
councils, candidates for mayor's post (wójt/burmistrz/prezydent) ${ }^{1}$, and the results of the elections. On their basis, a quantitative analysis was prepared showing the percentage share of party and nonpartisan lists as well as party and nonpartisan candidates in elections. The data were selected so that all provinces in Poland were examined (16), a number of districts were randomly selected (in provinces with less than 20 districts, data from half districts were examined, in provinces with over 20 districts, from one third). Within the selected districts, all communes were examined. Due to the assumed difference in results due to the size of the commune, in each province at least three-fourth of cities with over 20,000 residents constituting a separate voting circuit were examined, as well as all cities with over 100,000 residents (with the exception of the Silesia province in which only half of the cities with a population over 100,000 were examined to preserve the proportion). In total, data from 134 districts were analyzed, which is 43 percent districts in Poland and 908 communes (37 percent of communes in Poland), which allows the obtained data to be considered representative. Among communes, there were 735 communes up to 20,000 residents, 145 communes from 20,000 to 100,000 residents and 28 cities with over 100,000 residents.

I understand the term "partisan candidate/committee" as formally linked to a political party that participated in local elections, i.e. as a candidate/committee put forward and funded by a party. The term "non-partisan" refers in this article to candidates and committees which are not organizationally and financially linked to a political party, but are only local or regional, most often limited to one commune, district, and province.

\section{Political Parties in Local Government}

Already in the first local elections, in 1990, parties and political movements put forward less than half of all candidates. The rest were recommended by entities that did not identify themselves with any political organization, which gained a total of 47 percent of seats (Bąkiewicz, 2008, p. 206). Gendźwiłł (2012,p. 504) explains in this context, that the dominant ideology of the Polish local government reform, introduced in 1990, was anti-partisan. As the result ,the local government and party system in Poland evolved to a certain degree in isolation from - and even in opposition to - one another" (Gendźwiłł, Żółtak, 2014, p. 1143). Changes to electoral law, especially the introduction of single-mandate constituencies, have further weakened the position of political parties in local elections. In communes, where the proportional system was replaced by the majority system, the decrease in the share of party candidates amounted to 9 percentage points on average (Gendźwiłł, 2015, p. 78). The introduction of single-mandate constituencies in small communes increased the number of registered electoral committees. Many committees, however, have a very local character,

1 The name of the mayor's post in Poland depends on the size of the commune and the historical tradition. 
often putting forward individual candidates. More detailed analyzes prove that singlemandate constituencies increased the number of electoral committees, but they reduced the fragmentation of councils (Gendźwiłł, Żółtak, 2016, p. 110).

The participation of political parties in local governments has decreased even more with the direct elections of mayors. Many of them have gained the position of local leaders who can refuse political affiliation and get a mandate from their own electoral committee, based their candidacy mainly on their individual recognition and popularity and receiving the strong electoral legitimacy (Gendźwiłł, 2012,p. 503). There are situations when the winning candidate for mayor's post won the mandate for the first time starting as a candidate of a political party, and once again as a candidate of his own committee without the party's label.

The authors often emphasize that the law favors party committees in local government elections. B. Michalak explicitly states that in the local government elections, political parties are privileged in relation to other participants of electoral rivalry (Michalak, 2007, p. 184). As an example, he introduces the obligation to register electoral committees of voters in communes up to 20,000 residents, regulations on the names of committees, strict rules for financing and settlement of campaigns. The author states that overly formalized procedures, difficult to meet by local committees that do not have extensive organizational structures, may even discourage civic activity (Michalak, 2007, pp. 182-184). M. Mączyński indicates that in the regulations concerning the right to submit candidates to administrative bodies, political parties and coalitions of political parties were mentioned as first, and association, social organizations and voters as second. Mączyński also draws attention to the fact that the right to nominate a candidate for mayor's post is only held by the electoral committee, which registered the lists of candidates for councilors in at least half of the districts in a given commune, which in his opinion is preferential for large political parties (Mączyński, 2010, p. 33).

However, the presence of political parties in the local government cannot be viewed solely from the perspective of election results. Participation in deciding on local issues is often informal. M. Bąkiewicz states that political parties constitute a permanent element of the political landscape in the field of local government, strongly affecting its shape and activity, including through the influence on decisions taken at the central level (Bąkiewicz, 2008, p. 201). Many local politicians, parliamentarians, and political party activists have a strong position in their local community, even if they do not formally influence its fate.

The division of power between political parties and local communities applies only to communes and, in a certain part of the districts. Political parties have completely dominated the provincial local government. As L. Nikolski writes: province local governments have become the exclusive field of political party activity since the first term, they have assumed the role of regional parliaments in which the logic of national political rivalry applies, although sometimes in different configurations than at the central level (Nikolski 2011, p. 59). 
Literature often emphasizes that the actual level of presence of political parties in the local government is difficult to investigate, because often nonpartisan status is deceptive. The term "party camouflage" is even used. First, there are cases in which a political party actually operates under the aegis of a nonpartisan committee. In the history of local elections, it happened that political parties formed their own local electoral committees under a changed name, e.g. in 2002 Unia Wolności issued lists under the banner of "Unia Samorządowa", and PSL and PO registered lists in local communities under local names. This was not only for image-related reasons, but also for practical reasons; for the party to be protected from the consequences of possible errors in the settlement of campaigns at the local level (Rzeczpospolita, 2002). Secondly, as has been mentioned, the introduction of direct elections of city mayors gave them a strong position to apply for a mandate regardless of political affiliation. However, many independent candidates have a long and effective political career behind them. They were members of a party, and often its local leaders, members of parliament from partisan lists, etc. Exploring the partisan past of non-partisan candidates for mayors and councilors is an interesting issue for further research.

More important, however, is that many nonpartisan local committees act almost like a classic political party. The local quasi-party organization does not meet all the criteria for the definition of a political party, but it has a political character, as Gendźwiłł (2010,p. 100) emphasizes, even despite the declarations of its members. Local committees strengthen their position in the local community, often winning a dominant position for more than one term, have their own hierarchy, own program, and strive to achieve their own goals. What distinguishes them from the classic parties is primarily the lack of a clear ideological image (which is now also characteristic of political parties) and the locality of action, although with appropriate conditions, it is possible to expand the influence of such committees on the regional level (Cichosz, 2012, p. 79). Such quasi-parties also have a more ephemeral character, they cannot act as an opposition and in the case of defeat in elections they usually cease to exist. As Gendźwił writes: "Electoral committees putting forward lists for councilors are created on an ad hoc basis and it seems that they cannot be a substitute for a political party, and thus constitute a permanent political force in the local government for a long time" (Gendźwiłł 2008, p. 24).

For local quasi-party organizations, coalition partners are usually political parties, but, as indicated by Gendźwiłł (2010, p. 116), this cooperation is not strongly conditioned by the local context but very often the position of a given political party on the national scene (especially if the party participates in the exercise of power at the central level).

Bukowski, Flis, Hess, and Szymańska are very critical about hiding the real support of political parties for officially nonpartisan candidates, they call this hypocrisy and claim that such behavior leads to undermining the credibility of political parties (Bukowski et al., 2011, p. 60). However, Gendźwiłł emphasizes that nonpartisan movements, even if their nonpartisanship is a camouflage, can mobilize the energy of local activists and authorities who would not engage in political activity (Gendźwiłł, 2010, p. 117). 
In public opinion polls conducted over the past 20 years, local government authorities have always received generally positive ratings. A special increase in positive ratings followed Poland's accession to the European Union and the implementation of the first investment projects by Polish local governments thanks to EU funds. In 2018, the activity of local governments was rated well by 69 percent, more than twice as much as the Sejm and Senate (Gendźwiłł, Żerkowska-Balas, 2018, p. 20). Alongside the positive assessment of the local government, Poles appreciate the importance of local government elections: in 2014, 47 percent of Poles assessed them as very important (in the case of elections to parliament 41 percent, presidential 40 percent, the European Parliament 25 percent). The greatest importance is attributed to the elections of the city mayor (47 percent), slightly smaller to the elections to commune councils (36 percent). The opinion that the elections to the province council are the most important among the local elections, was shared by only 6 percent of the respondents (Gendźwiłł, Żerkowska-Balas, 2018, pp. 5-9).

The behavior and electoral decisions related to voting for local government are influenced by the fact that in almost three decades (since the first local election in 1990), the principles of local government elections have been changed several times. As Dudzińska (2008,p. 112) remarks, after each parliamentary election, some attempts have been made to 'improve' electoral law in a way favorable to the parties currently in power: „The interchanging rhythm of local and parliamentary elections has tempted members of subsequent parliaments to increase chances of their parties in local elections by changing rule". Already after the first local government elections, there were proposals for changes to the ordination, but no changes were introduced, and the subsequent elections in 1994 were carried based on the same rules. The first profound change in electoral law occurred 8 years after the restoration of democratic self-government in Poland and was linked to the fundamental reform of its structure and tasks. The number of voivodeships was reduced from 49 to 16, districts liquidated in the 1970s. were restored and the position of marshal of the voivodeship standing at the head of the regional government was introduced. After four consecutive years, it was decided to introduce direct elections of mayors - the first elections under the new rules were held on 27 October 2002. This solution has not only introduced new opportunities for non-partisan candidates but significantly changed the reciprocal position of the municipal council and the mayor, weakening the role of the former. The ordinance has been altered twice: in 2014, the proportional representation was only in force in the largest cities, and since 2018 this rule has also been extended to smaller cities - currently only in municipalities of up to 20,000 the majority electoral system still applies. Before the 2018 elections, a rule was also introduced limiting the number of mayor's term of office to 2 (previously he could apply for re-election without restrictions), while at the same time extending the term of office of all levels of local government from 4 to 5 years. As Gendźwiłł (2012, pp. 504-505) writes, „in the countries where political parties have weak local structures and are exceptionally distrusted, the introduction of the direct elections of mayors makes winning the elections without the support of a political party more possible". 
Raciborski (2012, pp. 14-15) also indicates complications caused by the fact that elections to various levels of government are carried out simultaneously: the voter receives as many as 4 different voting cards, the logic of proportional elections is mixed with the majority election logic, the significance of these choices is diversified. Added to this is the fact that over 40 percent of Poles believe that they have no impact on the affairs in their commune (Gendźwiłł, Żerkowska-Balas, 2018, p. 11). Kurczewski and Kurczewska (2001, p. 954) summarize the results of studies that show that political participation, privatization, or associational life are aggregated and interpreted mostly through events that also occur at the national level (parliamentary debates, economic legislation, nationwide public mobilization campaigns): „Local life, whether in metropolitan or rural areas, is therefore less visible and understood". All these factors cause that despite the high ratings of the local government and the sense of the importance of local elections, the election act itself is not deeply thought out, fully conscious, and rational. Raciborski (2012, p. 29) believes that the dominant feature of the group of electorally active Poles is ritualism, and participation in elections does not result from the acceptance of values and postulates of democracy. Dudzińska (2008, pp. 120-121) emphasizes that neither candidates, nor voters, perceive any special category of local election separately: it is the local election, and the term comprises all elections: to the commune, district and province councils.

The authors have long wondered what the significance of the party context is in the election decision made in the local government elections, especially whether the party label strengthens or weakens the chance of being elected. As Kolczyński and Farciak argue (2013, p. 85), almost half of respondents believe that assigning candidates in local government elections to specific political groups facilitates the decision-making process. However, party identification does not give an advantage, on the contrary, there is a view that it can be a significant weakness, especially in rural areas and in smaller cities. The attitude in which local voters are more willing to vote for a nonpartisan candidate is independent of party preferences. Research carried out in 2010 showed that among the potential voters of the three largest parties at the time (PiS, PO, and SLD) less than one third were guided by their political sympathies in the election of the mayor and commune councilors (Bukowski et al., 2011, p. 18). A. Gendźwiłł conducted research in three large urban centers regarding the reasons for the electoral victory of nonpartisan candidates for mayor's post. Respondents being nonpartisan local politicians, explaining support for nonpartisan candidates, indicated, among others, the dislike of political parties, which is understandable in and of itself. However, the justification of the anti-party attitudes is extremely interesting: respondents explained that political parties are undemocratic institutions, chiefly privatized, and centered around one leader (Gendźwiłł, 2010, p. 103). Such an assessment only appears logical and rational. It needs to be indicated that local quasi-parties rarely have a more democratic character, and, first of all, they are based on the authority of the leader. Moreover, in the same study, Gendźwiłł shows that councilors representing the nonpartisan committee show strong approval for the local government system with a strong presidential position and 
a weak position of the city council (Gendźwiłł, 2010,p. 107). The reluctance towards political parties at the local level is not an effect of conscious, thoughtful, and consistent attitudes, but only a cliché, the result of a superficial assessment of reality.

However, research shows that party affiliation or lack of it is not the most important factor determining the chances of being elected. First of all, it is important what political party the candidate represents: the nonpartisan candidate and the candidate representing the party with high popularity at the central level have similar chances. Secondly, as Grabowski (2016) established, whether the candidate is put forward by a party or nonpartisan committee is less important for the success in the election than whether the candidate is seeking re-election or running for the first time. A candidate applying for a re-election (incumbent) has a better chance than the pretender to the mandate, regardless of the party context of them both (Flis, 2011).

\section{Findings}

First, the proportions of party and nonpartisan committees which in 2018 introduced their candidates to local governments at all levels were examined.

Tab. 1. Party and nonpartisan committees which in 2018 introduced their candidates to local governments (in percent)

\begin{tabular}{lllll}
\hline \multicolumn{2}{l}{ The level of self-government } & Party & Nonpartisan \\
\hline \multirow{2}{*}{$\begin{array}{l}\text { Communal } \\
\text { councils }\end{array}$} & Generally & & $\mathbf{3 0}$ & $\mathbf{7 0}$ \\
\cline { 2 - 5 } & Including: & up to 20,000 residents & 27 & 73 \\
\cline { 2 - 4 } & 20,000-100,000 residents & 40 & 60 \\
\cline { 2 - 4 } & over 100,000 residents & 60 & 40 \\
\hline District councils & & $\mathbf{5 3}$ & $\mathbf{4 7}$ \\
\hline Province councils & & $\mathbf{8 8}$ & $\mathbf{1 2}$ \\
\hline
\end{tabular}

Table 1 shows that the committees that entered the councils of small and medium-sized communes (up to 100,000 residents) are mostly nonpartisan committees, however, in the case of the smallest communes (below 20,000), we can talk about a clear dominance: only 30 percent of electoral committees that have introduced lists to communal councils are committees of political parties. The situation is changing in the case of the largest cities (over 100,000), in which only 40 percent of committees with representatives in the council are nonpartisan committees. In the elections to district councils, as in the case of the largest cities, most lists taking part in the distribution of seats are lists of committees of political parties. Meanwhile, it should be noted that 83 percent of districts in Poland have less than 100,000 residents. The success of party lists, therefore, does not simply depend on the size of the community, voters treat the commune authorities in a different way as closer to themselves than the somewhat distant power in the district. Political parties dominate almost 
completely in regional governments assemblies: only 12 percent of lists that introduced their councilors to the province local government are lists of nonpartisan committees.

To show even more clearly the participation of nonpartisan committees in local governments, it was examined how many seats exactly were taken by the councilors running from these committees, and what percentage of seats are occupied by nonpartisan councilors in the councils of communes and districts and in provinces local governments.

Tab. 2. Number of seats taken by party and nonpartisan committees in 2018 (in percent)

\begin{tabular}{lllcc}
\hline \multicolumn{2}{l}{ The level of self-government } & & Party & Nonpartisan \\
\hline \multirow{3}{*}{$\begin{array}{l}\text { Communal } \\
\text { councils }\end{array}$} & Generally & & $\mathbf{3 0}$ & $\mathbf{7 0}$ \\
\cline { 2 - 5 } & Including: & up to 20,000 residents & 27 & 73 \\
\cline { 2 - 5 } & 20,000-100,000 residents & 23 & 77 \\
\cline { 2 - 5 } & over 100,000 residents & 70 & 30 \\
\hline District councils & & $\mathbf{9 6}$ & $\mathbf{4 6}$ \\
\hline Province councils & & & $\mathbf{4}$ \\
\hline
\end{tabular}

Table 2 shows that the vast majority of councilors sitting in the councils of small and medium-sized communes are councilors not officially affiliated with a political party, with the difference between small and medium-sized communes being small in this respect. In large cities as much as 70 percent of councilors are councilors from lists of political parties, with 22 percent of the examined councils that did not have a single council member elected from the nonpartisan committee. In districts, councilors from nonpartisan committees constitute a minority, though not pronounced. In local government assemblies, only 4 percent of councilors were not elected from the lists of political parties, with as many as 10 councils where there is not one councilor from a nonpartisan list, and in 3 regional councils there is only one such councilor.

The answer to the question why in the elections to commune councils of small and medium-sized communes, nonpartisan candidates are much more often selected is not possible without qualitative research. However, statistical data may also be helpful. Table 3 shows the proportions of all party and nonpartisan lists submitted in the election.

Tab. 3. Party and nonpartisan committees registered in the 2018 election

\begin{tabular}{lllcc}
\hline \multicolumn{2}{l}{ The level of self-government } & & Party & Nonpartisan \\
\hline \multirow{3}{*}{$\begin{array}{l}\text { Communal } \\
\text { councils }\end{array}$} & Generally & & $\mathbf{2 7}$ & $\mathbf{7 3}$ \\
\cline { 2 - 5 } & \multirow{2}{*}{ Including: } & up to 20,000 residents & 27 & 73 \\
\cline { 2 - 5 } & 20,000-100,000 residents & 40 & 60 \\
\cline { 2 - 5 } & over 100,000 residents & 52 & 48 \\
\hline District councils & & $\mathbf{5 1}$ & $\mathbf{4 9}$ \\
\hline Province councils & & & $\mathbf{2 6}$ \\
\hline
\end{tabular}


Please note that in the case of small and medium-sized communes, the ratio of party and nonpartisan lists that participated in the distribution of seats (Table 1) and the ratio of all party and nonpartisan lists submitted in elections is identical. The situation is similar in districts, although here the ratio is not perfectly consistent. Voters somewhat preferred to vote for candidates from lists of political parties. Things are quite different in the case of the councils of the largest cities and regional assemblies, where voters have clearly favored party lists. This dependence can be seen better in the next table, in which the so-called "success rate" has been calculated, that is the ratio of the submitted lists to the lists participating in the distribution of seats (this coefficient ranges from 0 to 1 , where 0 means that for every 10 lists submitted, not one has introduced their representatives to the council and 1, that for every 10 submitted lists, each has its representatives in the council).

Tab. 4. Success rate for party and nonpartisan committees in 2018 election

\begin{tabular}{llllc}
\hline \multicolumn{2}{l}{ The level of self-government } & Party & Nonpartisan \\
\hline \multirow{3}{*}{$\begin{array}{l}\text { Communal } \\
\text { councils }\end{array}$} & Generally & & $\mathbf{0 , 6 7}$ & $\mathbf{0 , 6 5}$ \\
\cline { 2 - 4 } & \multirow{2}{*}{ Including: } & up to 20,000 residents & 0,65 & 0,65 \\
\cline { 2 - 4 } & 20,000-100,000 residents & 0,78 & 0,75 \\
\cline { 2 - 4 } & over 100,000 residents & 0,59 & 0,36 \\
\hline District councils & & $\mathbf{0 , 8 3}$ & $\mathbf{0 , 7 7}$ \\
\hline Province councils & & $\mathbf{0 , 3 5}$ & $\mathbf{0 , 1 4}$ \\
\hline
\end{tabular}

Please note that in the case of the smallest communes, party and nonpartisan lists have exactly the same ratio, which means that party and nonpartisan lists had the same chance in the elections. In the case of medium-sized communes, and even in the case of districts, these numbers are also similar. If we compare the data from Tables 1, 3, and 4, we can conclude that the significant advantage of nonpartisan committees in the councils of small and medium-sized communes and districts does not result from favoring such committees by voters, but is a simple consequence of such and no other election offer. In other words: in the elections to the councils of small and medium-sized communes and district councils the lists of nonpartisan committees won more often, because there was just more of them. Where a strong political party list was reported, it had the exact same chance of winning as the nonpartisan list. The disproportions between the number of party and nonpartisan lists in individual communes were sometimes very large, there were many communes in which no party list was registered. Among the surveyed communes, the record fell in the Krokowa commune (Puck district, Pomeranian province), in which 13 lists of nonpartisan committees were registered without a single list of political parties.

A different situation occurred in the case of elections to the councils of the largest cities and province councils, in which the success rate of lists issued by political parties was significantly higher than the nonpartisan lists. This means that voters have favored lists of 
party committees. This is particularly evident in the largest cities, in which the proportion of party and nonpartisan lists was very even (52:48), yet the chances of party lists turned out to be over 20 percentage points higher than the lists of nonpartisan committees.

The next chart presents the results of the election of city mayors. These are important data, as, unlike in the results of the elections to councils, we can partially capture the "camouflaged party", and thus isolate those candidates who formally were put forward from nonpartisan lists, but are members of political parties or had their official support.

Tab. 5. Party and nonpartisan candidates elected for mayor's posts (in percent)

\begin{tabular}{llccc}
\hline & $\begin{array}{c}\text { Candidates of } \\
\text { nonpartisan } \\
\text { committees }\end{array}$ & $\begin{array}{l}\text { Candidates of nonpar- Candidates } \\
\text { tisan committees who of political parties } \\
\text { are party members or } \\
\text { have a party's official } \\
\text { support }\end{array}$ & \\
\hline Generally & $\mathbf{6 8}$ & $\mathbf{1 5}$ & $\mathbf{1 7}$ \\
\hline \multirow{2}{*}{$\begin{array}{l}\text { Includ- } \\
\text { ing: }\end{array}$} & up to 20,000 residents & 70 & 13 & 17 \\
\cline { 2 - 6 } & 20,000-100,000 residents & 64 & 21 & 32 \\
\hline
\end{tabular}

The chart shows that as much as 83 percent of the mayors elected in 2018 are selected from lists of nonpartisan committees, with 15 percent being candidates who are party members or have entered the race with a party's official support. Thus, it can be said that it is the mayor offices that are the least partisan element of local government in Poland, more so that the dominance of nonpartisan candidates is visible regardless of the size of communes and applies even to cities with over 100,000 residents whose councils are clearly partisan.

As in the case of the elections to the councils and regional assemblies, it was checked how the results of presidential elections are related to the election offer, hence, whether a high percentage of selected people who did not run from the lists of political parties resulted from a small number of political party candidates.

Tab. 6. Party and nonpartisan candidates for mayor's posts registered in 2018 election (in percent)

\begin{tabular}{|c|c|c|c|c|}
\hline & & $\begin{array}{l}\text { Candidates of } \\
\text { nonpartisan } \\
\text { committees }\end{array}$ & $\begin{array}{l}\text { Candidates of nonpar- } \\
\text { tisan committees who } \\
\text { are party members or } \\
\text { have a party's official } \\
\text { support }\end{array}$ & $\begin{array}{l}\text { Candidates } \\
\text { of political parties }\end{array}$ \\
\hline Generally & & 60 & 10 & 30 \\
\hline \multirow[t]{3}{*}{ Including: } & $\begin{array}{l}\text { up to } 20,000 \\
\text { residents }\end{array}$ & 65 & 10 & 25 \\
\hline & $\begin{array}{l}20,000-100,000 \\
\text { residents }\end{array}$ & 49 & 12 & 39 \\
\hline & $\begin{array}{l}\text { over } 100,000 \\
\text { residents }\end{array}$ & 43 & 12 & 45 \\
\hline
\end{tabular}


The table shows that the candidates for the post of the mayor were primarily representatives of nonpartisan committees, some of whom were members of political parties or received official support from a party. The comparison of data from Tables 5 and 6 shows that voters in the largest cities more willingly chose nonpartisan candidates, despite the fact that they were fewer than the candidates proposed by political parties. For a better comparison of the election results with the electoral offer, the success rate was calculated, i.e. the ratio of proposed candidates to the candidates who won the mandate ( 0 means that for every 10 candidates, none won a mandate and 1 that everyone received a mandate for every 10 candidates).

Tab. 7. Success rate for party and nonpartisan candidates for mayor's posts in 2018 election

\begin{tabular}{llccc}
\hline & & $\begin{array}{l}\text { Candidates of } \\
\text { nonpartisan com- } \\
\text { mittees }\end{array}$ & $\begin{array}{l}\text { Candidates of nonparti- } \\
\text { san committees who are } \\
\text { party members or have } \\
\text { a party's official support }\end{array}$ & $\begin{array}{l}\text { Candidates of } \\
\text { political parties }\end{array}$ \\
\hline Generally & $\mathbf{0 , 4}$ & $\mathbf{0 , 4 9}$ & $\mathbf{0 , 1 9}$ \\
\hline $\begin{array}{l}\text { Includ- } \\
\text { ing: }\end{array}$ & up to 20,000 residents & 0,39 & 0,51 & 0,24 \\
\cline { 2 - 5 } & 20,000-100,000 residents & 0,52 & 0,44 & 0,10 \\
\hline
\end{tabular}

In all cases, it is clear that residents of communes and cities, regardless of their size, favored nonpartisan candidates, including candidates who were party members or who were supported by a party. Table 7 shows that it were the nonpartisan candidates who were party members or were officially supported by a political party, regardless of the size of the city, that had the best chance of being elected: every other candidate of this type had a statistical chance to be elected. On the basis of a more accurate analysis of the data, it can be assumed that the high popularity of nonpartisan candidates with the support of party or party members results from the fact that many of them represented the same political career model: they were leaders of the local community applying for reelection, strong and popular, that they could set up their own committee, and many times in the previous elections they applied for the same position from the list of political parties. In table 7, noteworthy is the extremely low success rate of candidates of political parties: in medium and large cities only one in ten party candidates had a chance to win. The regularity is visible, in which the mayor from a political party is reluctantly selected in large and medium-sized cities, but the lists of political parties in the commune council elections are voted for relatively willingly. This proves the thesis that the mayor's election is personal in nature, the vote is given to a person known to the local community, and not to a political party. 


\section{Summary}

The quantitative research shows that local governments elected in 2018 are not political only in small and medium-sized communes, in which the councils are made up mostly of councilors who were candidates from nonpartisan committees. This state of affairs, however, is not the result of a conscious decision of voters, the willingness to support nonpartisan committees or the commune government being closed to political parties. The choice made by voters is the result of poor electoral offer proposed in small and medium-sized communes by political parties. What is more, in the elections to the councils of the largest cities, district councils and regional government assemblies, where the offer of political parties and nonpartisan committees was similar, voters statistically voted more eagerly on the lists of political parties.

The thesis that the low degree of partisanship of communal governments is the weakness of political parties at the local level is present in the literature on the subject (see: Gendźwiłł, 2010,p. 100). Political parties have not developed their structures in small- and medium-sized cities. As explained by L. Nikolski, the reason is the top-down, parliamentary genesis of the majority of political parties in Poland (Nikolski, 2011, p. 38). Meanwhile, in large cities and at the regional level, the structures of political parties work quite well, moreover, alternative, especially supra-local government organizations have not developed there, and the level of anonymity of candidates for councilors is increasing (Kostka, 2008, p. 148).

The high level of support for candidates for mayor's post running from their own nonpartisan electoral committees shows that these elections are personal, candidates are known to voters, often personally, and party affiliation as a facilitator of making an electoral decision is not necessary. It should be noted that the candidates' independence is often apparent, among them are candidates belonging to one of the parties or officially supported by them.

Attempts at convincing that the low participation of political parties in local governments of communes, especially small and medium-sized ones, is evidence of the society's maturity, their involvement in the life of the local community or the desire to cut the party off from deciding about the immediate environment are wrong, because they stem from the lack knowledge of the actual causes of this phenomenon. The analysis of the results of quantitative research on data from the local government elections of 2018 may suggest that for the voter, the level of party or nonpartisan nature of the local government is not significant. The voter votes in the first place for a candidate he or she knows (this can be seen mostly in the elections for the post of mayor and councilor in small communes). In the elections to local governments in large cities, to the council of the district and the regional government assembly, the voter is in turn guided by the party's label, favoring the lists of political parties. Such a picture of local government will be perpetuated. Despite high local government ratings in opinion polls, it is not the center of social activity, there is a clear 
reluctance to engage and weakness of group participants in the local political and social life (Kostka, 2008, pp. 93-94). The institutional weakness of political parties, especially the lack of local structures, also seems to be a permanent phenomenon (Nikolski, 2011, p. 39). This is the only chance for local nonpartisan committees to succeed in the elections.

\section{References}

Bąkiewicz, M. (2008). System wyborczy do samorzadu terytorialnego w Polsce na tle europejskim. Toruń: Wydawnictwo Adam Marszałek.

Bukowski, M., Flis, J., Hess, A., Szymańska, A. (2011). Opcja czy osoba? Upartyjnienie versus personalizacja w wyborach samorzadowych. Kraków: Wydawnictwo Uniwersytet Jagiellońskiego.

Cichosz, M. (2012).„,Wybory prezydenta we Wrocławiu”, In: Ł. Tomczak, Prezydenci miast, analiza rywalizacji w wyborach samorzadowych, Wrocław: Wydawnictwo Marina

Cichosz, M., Starzyk A. (2017). Przyszli władcy regionów. Rzecz o kandydatach w wyborach do sejmików województw w 2014 r., In R. Alberski, M. Cichosz, Gra o regiony 2014. Wybory do sejmików województw, Wrocław: Instytut Politologii Uniwersytetu Wrocławskiego.

Dudzińska, A. (2008). Non-party Lists in Local Election in Poland. In M. Reiser, E. Holtmann, Farewell to the Party Model?. Wiesbaden: VS Verlag für Sozialwissenschaften.

Flis, J., (2011). Partie polityczne w wyborach prezydentów miast. Studia Politologiczne, pp. 139-159.

Gendźwiłł, A. (2008). Dlaczego sukces? Analiza wyników wyborów prezydentów największych polskich miast. In J. Raciborski, Studia nad wyborami, Polska 2005-2006. Warsaw: Wydawnictwo Naukowe Scholar, pp. 13-47.

Gendźwiłł, A. (2010). Bezpartyjni prezydenci miast i ich znaczenie dla lokalnej polityki. Studia Regionalne i Lokalne, No. 2, pp. 99-120.

Gendźwiłł, A. (2012). Independent Mayors and Local Lists in Large Polish Cities: Towards a Non-partisan Model of Local Government?. Local Government Studies, No. 4, pp. 501-518.

Gendźwiłł, A. (2015). Zmiany niezauważone? O tym, jak zadziałały jednomandatowe okręgi wyborcze w wyborach do rad gmin w 2014 roku. In Co się stało 16 listopada? Wybory samorzadowe 2014, Warsaw: Fundacja Stefana Batorego.

Gendźwiłł, A., Żółtak, T. (2012). Bezpartyjność w powolnym odwrocie. Analiza rozpowszechnienia bezpartyjności w wyborach lokalnych $w$ Polsce w latach 2002-2010. Studia Regionalne i Lokalne, No. 1, pp. 102-121.

Gendźwiłł, A., Żółtak, T. (2014). Why Do Non-partisans Challenge Parties in Local Politics? The (Extreme) Case of Poland. Europe-Asia Studies, No. 7, pp. 1122-1145.

Gendźwiłł, A.,Żółtak, T. (2016). Skutki wprowadzenia okregów jednomandatowych w wyborach lokalnych. Studia Regionalne i Lokalne, No. 3, pp. 94-116.

Gendźwiłł, A.,Żerkowska-Balas, M. (2018). Polacy o samorzadach. Opinia publiczna u progu samorzadowej kampanii wyborczej. Warsaw: Fundacja im. Stefana Batorego.

Grabowski, W. (2016). Czynniki determinujące reelekcję prezydentów polskich miast. Studia Regionalne i Lokalne, No. 4, 97-114.

Kolczyński, M, Faracik-Nowak, M. (2013). Samorzadność a przynależność partyjna. Political preferences, No. 7, pp. 81-91. 
Kostka,W. (2008). Instytucjonalizacja partii politycznych w społecznościach miejskich. Toruń: Wydawnictwo Adam Marszałek.

Kurczewski, J., Kurczewska, J. (2001). A Self-Governing Society Twenty Years After: Democracy and the Third Sector in Poland. Social Research, No. 4, pp. 937-976.

Mączyński, M. (2010). Uniformizacja wyborów samorządowych w gminie? Dylematy ustrojowe i polityczne. In M. Stec, K. Małysa-Sulińska, Wybory i referenda lokalne. Aspekty prawne i politologiczne, Kraków: Wolters Kluwer Polska, pp. 29-36.

Michalak, B. (2007). Prawne ramy rywalizacji wyborczej w wyborach do organów samorząu terytorialnego $w$ Polsce. In J. Marszałek-Kawa (ed.), Samorzad terytorialny. Studium politologiczne, Torun: Wydawnictwo Adam Marszałek, pp. 165-185.

Nikolski, L. (2011). Partie polityczne w wyborach do sejmików województw 1998-2006. Toruń: Wydawnictwo Adam Marszałek.

Raciborski, J. (2012). Instytucjonalne uwarunkowania zachowań wyborczych. Toruń: Wydział Prawa i Administracji Uniwersytetu Mikołaja Kopernika.

Rzeczpospolita. (2002). Zakamuflowane komitety. Rzeczpospolita, 16.09.

Swianiewicz, P. (2010). Bezpartyjni radni w samorzadach gminnych. Samorząd terytorialny, No. 11, pp. 18-43.

\section{Author}

\section{Assoc. Prof. Marcin Czyżniewski}

Nicolaus Copernicus University in Toruń. Contact details: mcz@umk.pl 